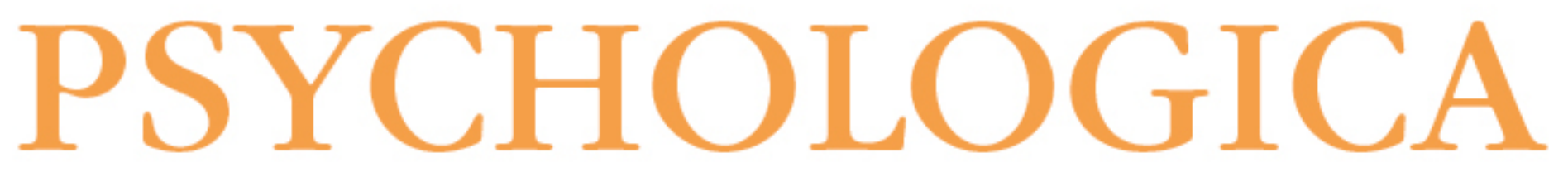

\title{
Memórias afectivas do corpo: um estudo qualitativo acerca do papel dos pais na experiência corporal
}

Autor(es): $\quad$ Barbosa, Raquel; Matos, Paula Mena; Costa, Maria Emília

Publicado por: Imprensa da Universidade de Coimbra

URL

persistente: URI:http://hdl.handle.net/10316.2/5423

DOI: DOI:http://dx.doi.org/10.14195/1647-8606_50_4

Accessed : $\quad$ 26-Apr-2023 13:11:56

A navegação consulta e descarregamento dos títulos inseridos nas Bibliotecas Digitais UC Digitalis, UC Pombalina e UC Impactum, pressupõem a aceitação plena e sem reservas dos Termos e Condições de Uso destas Bibliotecas Digitais, disponíveis em https://digitalis.uc.pt/pt-pt/termos.

Conforme exposto nos referidos Termos e Condições de Uso, o descarregamento de títulos de acesso restrito requer uma licença válida de autorização devendo o utilizador aceder ao(s) documento(s) a partir de um endereço de IP da instituição detentora da supramencionada licença.

Ao utilizador é apenas permitido o descarregamento para uso pessoal, pelo que o emprego do(s) título(s) descarregado(s) para outro fim, designadamente comercial, carece de autorização do respetivo autor ou editor da obra.

Na medida em que todas as obras da UC Digitalis se encontram protegidas pelo Código do Direito de Autor e Direitos Conexos e demais legislação aplicável, toda a cópia, parcial ou total, deste documento, nos casos em que é legalmente admitida, deverá conter ou fazer-se acompanhar por este aviso. 


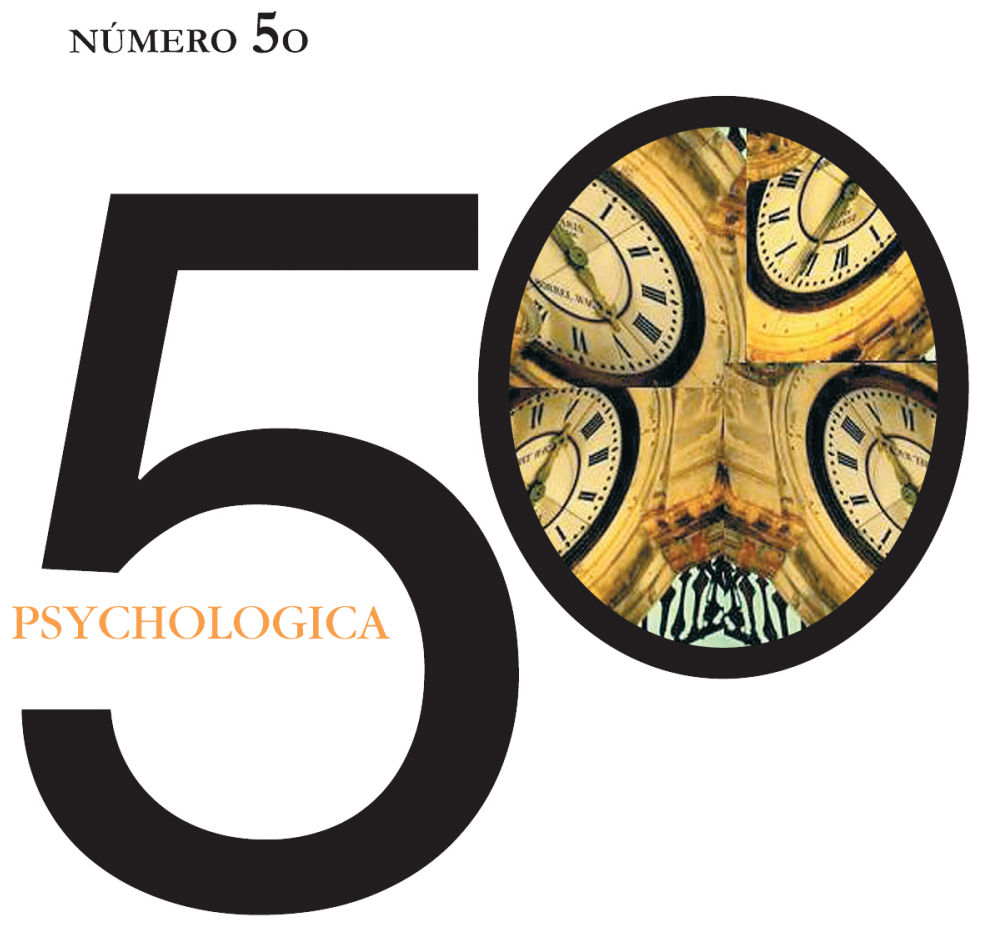

IMPRENSA DA UNIVERSIDADE DE COIMBRA

FACULDADE DE PSICOLOGIA E DE CIÊNCIAS DA EDUCAÇÃO DA UNIVERSIDADE DE COIMBRA 


\title{
Memórias afectivas do corpo: um estudo qualitativo acerca do papel dos pais na experiência corporal'
}

\author{
Raquel Barbosa, Paula Mena Matos \& Maria Emília Costa²
}

Neste estudo estamos interessados em compreender melhor os pensamentos e sentimentos subjacentes à experiência do corpo no contexto familiar. Pretende-se escutar as vozes dos adolescentes no que diz respeito à representação da relação que estabelecem com o seu corpo e com o mundo, escutar e compreender, através de entrevistas semi-estruturadas, as narrativas pessoais dos participantes relativamente à construção da sua experiência corporal. A entrevista focaliza-se, essencialmente, na construção de significados acerca do corpo ao longo do desenvolvimento (a vivência do corpo relacional e emocional desde a infância até ao momento da entrevista), tendo em conta a qualidade das relações estabelecidas com os pais.

Devido à ausência de estudos neste domínio, este trabalho pretende ser um eventual contributo para a compreensão do corpo enquanto experiência relacional e ajudar a compreender como é que os adolescentes e jovens falam do seu corpo.

PALAVRAS-CHAVE: Vivência corporal; Relação parental; Narrativas pessoais; Adolescência.

\section{Introdução}

Como qualquer outra realidade do mundo, o corpo é socialmente construído. As pessoas aprendem a avaliar os seus corpos através da interacção com o ambiente, com os outros.

Ao longo do ciclo de vida, muitas são as tarefas desenvolvimentais que exigem a reestruturação dessa estrutura que integra a corporeidade no self e que lida com as mensagens corporais - a sexualidade na adolescência, a construção da intimidade, a gravidez. Nessas alturas será desejável que as asserções relacionadas

\footnotetext{
1 Estudo inserido no Projecto POCTI/ PSI 61722/ 2004, financiado pela Fundação para a Ciência e a Tecnologia (Ministério da Ciência, Tecnologia e Ensino Superior)

2 Faculdade de Psicologia e de Ciências da Educação da Universidade do Porto

Gostaríamos de agradecer a todos aqueles adolescentes e jovens que generosamente partilharam as suas histórias e o seu tempo, tornando possivel este estudo!
} 
com a vivência corporal de cada um sejam integradas numa estrutura mais complexa de funcionamento e desenvolvimento psicológico. Este desenvolvimento e complexificação dos padrões de relação com o corpo dependem, por seu lado, da história de vida e dos contextos sociais em que o sujeito se move, que facilitarão ou dificultarão determinados padrões de relacionamento do indivíduo com o seu eu corporal, a sua condição incorporada. Assim, a incorporação ou corporeidade vão ser reconstruídos na adolescência. Através das novas competências de abstracção, o sujeito torna-se capaz de empreender um processo narrativo no qual reestrutura toda a sua história de vida, todo o conhecimento adquirido até então.

Recentemente tem havido um crescente interesse nos processos de vinculação adulta e a sua relação com o desenvolvimento da imagem corporal. Ao longo da vida, as experiências como a crítica à a parência e outros processos sociais e interpessoais que estão subjacentes ao desenvolvimento da segurança nas relações de vinculação, poderão levar à construção de esquemas pessoais, interpessoais e de aceitação física que, por seu lado, poderão levar à insegurança e ansiedade em relacionamentos sociais e íntimos subsequentes (ex. Barbosa, 2001; Barbosa \& Costa, 2001a, 2001b, 2001/2002, 2003; Benedikt, Wertheim, \& Love, 1998; Hart \& Kenny, 1997; Moreno \& Thelen, 1993; Thelen \& Cormier, 1995; Mukai, 1996; Salzman, 1997; Ward, Ramsay, \& Treasure, 2000; Vincent \& McCabe, 2000). Assim, desde a infância, as percepções corporais estão intrinsecamente ligadas à qualidade da relação da criança com os seus significativos, que, por sua vez, são influenciados pelas normas e valores sociais. Por conseguinte, a corporeidade depende deste mesmo jogo de interacções relacionais de forças internas, psicológicas e externas, de importantes e poderosos agentes de socialização como os meios de comunicação social, a família, e, sobretudo na adolescência, os pares, representa como que a síntese viva de todas as nossas experiências emocionais. Neste estudo iremos enfatizar precisamente um destes contextos basilares de desenvolvimento a família, particularmente a relação parental desde a infância.

Na primeira infância a criança e o outro são experienciados em relação e vividos pela criança sob a forma de sensações e experiências corporais, e é a partir desta condição básica da existência - a corporeidade - que todo o desenvolvimento humano acontece. É através de uma estrutura maioritariamente biológica, corporal e sensorial, bastante hedonista, que a criança é orientada para o interrelacionamento e a partir do qual se constrói o self. Esta estimulação essencialmente física constitui, portanto, um veículo de comunicação fulcral e é também um dos meios mais utilizados nos contextos relacionais para expressar emoções ao outro. Efectivamente, o toque é o canal mais intenso de comunicar com o outro e aquele sobre o qual a maioria das pessoas tem mais relutância em discutir. Autores como Hunter e Struve (1998, p. 3) definem o toque com o "processo principal através do 
qual os seres humanos obtêm informações sobre o mundo" ou Montagu (1986, p.1) como "a mãe de todos os sentidos". Mas como é que as crianças aprendem os diferentes significados acerca do toque? De facto, como referimos, até por volta dos 3, 4 anos de idade o toque revela-se como a modalidade sensorial dominante e só há medida que a criança cresce é que a visão parece assumir a mesma ou maior dominância (Itakura \& Imamizu, 1994). Os bebés são, portanto, essencialmente, seres sensoriais, eles apreendem o mundo usando os seus sentidos e o ambiente é definido pela forma como o bebé o sente - como é que o vê, como é que o cheira, a que é que sabe, como é que soa. Assim, a experiência táctil será o primeiro sentido desenvolvido pelos seres humanos e talvez o último a desaparecer.

Merleau-Ponty (1999) foi pioneiro, antecipando os insights posteriores da Psicologia do Desenvolvimento, descrevendo a criança como um ser aberto aos outros: sensível, desde muito cedo, às expressões dos outros, por exemplo, ao sorriso - uma sensibilidade tanto emocional como imediata. Deste modo, a criança e o outro não coexistem como seres psíquicos desembodied/ desencorporados, mas partilham um espaço embodied, no qual a comunicação é formada por acções corporais. Numa perspectiva desenvolvimental, a criança e o adulto comunicam não-verbalmente um com o outro. De facto, inicialmente a criança encontra nos comportamentos e acções do adulto o seu próprio corpo: o bebé espontaneamente imita as expressões faciais e corporais do adulto. Esta noção assemelha-se aquilo que Winnicot (1953) enfatiza também, isto é, o papel crucial do 'espelho' no desenvolvimento - a mãe como espelho do bebé, este encontra-se na face do outro (não apenas uma experiência visual, mas também táctil e gestual). Nesta troca de gestos e imitações são partilhados significados, e estados afectivos emergem (Diamond, 2001). Com efeito, o significado emerge daquilo que é inicialmente uma imitação, para ser estabelecido, mais tarde, linguisticamente.

Assim, é este compromisso e relação directa com o outro que tem grandes implicações para a experiência sensorial do corpo. Relembrando Merleau-Ponty (1999), as sensações internas estão sempre relacionadas com o ambiente e com a interacção com o outro, podendo afirmar-se então que quando nascemos o nosso corpo não é separado do corpo do outro, mas partilhamos um espaço no qual, inicialmente, experienciamos o nosso corpo com os outros corpos, descobrindo os nossos próprios gestos nos deles. Este núcleo tácito e primário de auto-conhecimento, anterior à linguagem, é largamente determinado pela forma de interacção corporal que os pais estabelecem com o bebé e com a criança: através da forma como comunicam estados emocionais, partilham e co-constroem padrões de proximidade e de responsividade físicas (Guidano \& Liotti, 1983).

Efectivamente as relações com as figuras de vinculação nos contextos de vida primeiramente influenciadores, como é o caso da família, determinam formas 
de interacção corporal que condicionarão (ainda que de forma não determinista) a estrutura tácita de relação do sujeito consigo e com os outros, no sentido de valorizar mais ou menos as mensagens e sensações corporais na expressão e experienciação do self. O tema do corpo leva-nos às origens e premissas básicas da teoria da vinculação que nos dizem que, desde o início da vida, o ser humano tem uma necessidade primária de estabelecer um laço emocional com uma figura adulta e de que a proximidade e o contacto físico são elementos fundamentais para o estabelecimento de laços emocionais de vinculação (Ainsworth et al. 1978; Bowlby, 1958, 1963, 1978a, 1978b, 1980; Hazan \& Zeifman, 1994). A vinculação é vista como uma motivação básica, tão importante como a de alimentação ou a sexual, existindo no ser humano uma necessidade profunda de contacto físico com o outro, não só intimamente, mas também de forma mais casual e social. Assim, a forma como o sujeito vive o seu corpo e constrói o seu self corporal está necessariamente relacionada com a vivência corporal daqueles que o rodeiam, nomeadamente os mais significativos, principalmente nas relações precoces. As experiências precoces que envolvam o corpo e o contacto físico, como os jogos familiares, os carinhos, os cuidados corporais e outros, podem ser considerados determinantes para a relação, aceitação e valorização que o sujeito faz do seu corpo. É na sequência de experiências desta natureza, mais ou menos repetitivas, que o recém-nascido vai adquirindo as informações mais valiosas sobre o seu corpo e o contexto que o rodeia (Hunter \& Struve, 1998). De facto, o contacto físico criança-mãe é revelado como veículo de comunicação fundamental na transmissão de sentimentos de 'segurança sentida' (Sroufe \& Waters, 1977).

Apesar da figura materna ser sempre a mais enfatizada, é muito importante também para o pai o estabelecimento destes primeiros laços. Vários estudos demonstraram que os pais que tinham um contacto precoce com os seus filhos tinham uma ligação mais forte com eles após alguns meses do nascimento. Uma vinculação forte com o pai é demonstrada através do contacto físico e enquanto este pega na criança, favorecendo o contacto ocular entre eles (Klaus \& Kennell, 2000). Na verdade, parece que chegaram ao fim os tempos em que se ignorava ou minimizava a contribuição do pai no desenvolvimento dos seus filhos. No entanto, como já referimos, os padrões de interacção entre mãe-criança e pai-criança serão distintos, isto é, a mãe mais associada a comportamentos de cuidadora e afectuosa, enquanto que a figura paterna é mais ligada a interacções de afiliação e brincadeiras (Geider, 1996; Grossmann, Grossman, Fremmer-Bombik, Kindler, Scheuerer-Englisch, \& Zimmermann, 2002). De uma forma geral, a interacção com o pai parece ser mais física, enquanto que com a mãe será mais verbal, com actividades como ler e cantar para os filhos (Lamb, 1977; Parke \& Tinsley, 1981). Tais brincadeiras mais vigorosas dos pais com as crianças, poderão proporcionar excitação e um desafio a vencer medos (Lamb, 1997). Vários estudos têm demons- 
trado uma relação entre as actividades e interacções positivas entre pai e filhos e resultados positivos para os filhos (Lamb, 2004; Shannon, Tamis-LeMonda, London, \& Cabrera, 2002), além de contribuírem para uma vinculação segura (Grossman et al., 2002). Independentemente destas diferenças na interacção parental, será consensual que as crianças constroem relações de vinculação com ambas as figuras parentais entre os 8 e os 18 meses (Lamb, 1977, 1997; Main \& Weston, 1981). Porém, a intensidade do comportamento de vinculação dirigido ao pai e a emergência destes comportamentos ao longo do desenvolvimento sugere que a figura paterna não será a figura primária de vinculação para a maioria das crianças (ex. Lamb, 1977).

Ademais, os papéis parentais são definidos biológica e socialmente, e consequentemente, os cuidados parentais também estão sujeitos a normas e regras sociais vigentes (ex. aprovação ou não do uso do toque físico nos diversos contextos relacionais, Hunter \& Stuve, 1998).

Além disso, mais do que a quantidade de contacto físico, é a sua qualidade que assume um papel determinante para o estabelecimento de relações de vinculação seguras e que as diferenças numa dimensão emocional, como é o contacto físico, com as mães têm implicações noutra, como a segurança. Consistente com esta interpretação, outros estudos têm corroborado a importância do contacto físico para a construção de relações de vinculação seguras, apelando à sensibilidade e responsividade das mães às necessidades dos filhos (ex. Anisfeld, Casper, Nozyce, \& Cunningham, 1990; Brazelton, 1995; Klaus \& Kennell, 2000; Thomaz, Lima, Tavares \& Oliveira, 2005). Main (1990) demonstra também a continuidade intergeracional na aversão ao contacto físico, constatando que as crianças, cujas mães rejeitavam o contacto da criança, assumiam o padrão da mãe e deixavam de desejar o contacto, mesmo em situações de stresse. Verificou, igualmente, que a aversão parental ao contacto físico está relacionada com a própria rejeição por parte dos pais durante a infância.

Por seu lado, a investigação tem documentado as implicações destas vivências para as relações de vinculação adulta, salientando o papel que o toque e o corpo têm no estabelecimento e manutenção da intimidade física e psicológica, nomeadamente que as diferenças individuais na aversão ao contacto físico, têm implicações na qualidade da formação das relações amorosas no futuro (Brennan, Wu, \& Loev (1998). Será razoável considerar que os evitantes do toque, do contacto físico com o outro, sejam os evitantes nas relações amorosas e assim não permaneçam na relação o tempo suficiente para que esta alcance um nível de intimidade indesejado (Ibidem).

Assim, com o complexificar das estruturas cognitivas, e com a capacidade do pensamento abstracto na adolescência, a atenção desloca-se para aspectos mais 
construídos e menos sensoriais das experiências de corporeidade. É, principalmente, a partir desta fase que muitas pessoas perdem a sintonia com o seu corpo, começam a estar preocupadas com o self corporal construído com base na moda, no que é desejável e no modo como o seu corpo se afasta desses padrões. Isto é, há uma valorização da exterioridade da corporeidade. É nesta fase, fundamental para a construção da autonomia do adolescente, que a centralidade da relação com os pais é substituída pela relação com o grupo de pares. No caso da adolescência e idade adulta, o significado relacional do toque, além da sua interpretação essencialmente ligada à expressão de intimidade, de afecto e cuidados, está também ligado às funções afectivas da sexualidade, nas quais o toque e o contacto físico têm um papel fundamental.

A investigação tem dado mais atenção às fases precoces da vida, centrando-se menos na relação entre o toque e o bem-estar aquando adultos, no entanto, de uma forma geral, a evidência apoia o pressuposto da necessidade humana do toque e de ser tocado até à adolescência e em adulto.

O grande objectivo deste estudo é, precisamente, escutarmos as vozes dos adolescentes no que diz respeito à representação da relação que estabelecem com o seu corpo e com o mundo, salientando-se a família como um dos seus principais contextos de desenvolvimento e a forma como este contexto foi interagindo entre si, no sentido de proporcionar a organização das vivências passadas e presentes destes adolescentes e jovens. É neste âmbito que recorremos a uma abordagem qualitativa e a entrevistas semi-estruturadas, tentando-se aceder às principais temáticas e narrativas associadas ao corpo desde a sua infância até aos dias de hoje. Este estudo explora, desta forma, a relação entre as memórias retrospectivas da afectividade, de proximidade, de relações afectivas de vinculação parental e a forma como as pessoas se sentem com o seu corpo. Existe uma relação entre as memórias de afecto recebidas pelos significativos e uma relação positiva e construtiva com o seu corpo?

Neste sentido, as questões é que constituem o ponto de partida para a recolha de informação, sendo privilegiada uma abordagem indutiva e holística, visando potenciar o desenvolvimento do conhecimento acerca desta temática do corpo construído na relação e em relação. São escassos os estudos de natureza qualitativa a abordar a imagem corporal e a vivência corporal, num sentido mais lato (são excepções Gupta \& Schork, 1995; Halliwell \& Dittmar, 2003; McCabe, Ricciardelli \& Ridge, 2006; Paquette \& Raine, 2004; Polce-Lynch, Myers, Kilmartin, Forssmann, \& Klewer, 1998; Rosen, Orosan-Weine, \& Tang, 1997; Wertheim, Paxton, Schutz, \& Muir, 1997). Assim, embora a importância das relações afectivas e do toque esteja bem documentado na literatura, constata-se a necessidade de mais investigação para uma melhor compreensão do papel específico da qualidade da relação esta- 
belecida com os outros e a capacidade de construir uma vivência corporal positiva. Desta forma, este estudo será, fundamentalmente, de carácter exploratório. Nesta exploração das suas histórias de vida, focalizamo-nos particularmente na forma como os adolescentes falam do seu corpo actualmente, como falam dele no passado, particularmente como falam do seu corpo e das suas relações afectivas com os seus pais.

\section{Metodologia}

\section{Participantes}

A amostra inquirida neste estudo foi seleccionada aleatoriamente de um estudo prévio, de natureza quantitativa, com 690 participantes, onde se avaliou a imagem corporal relativamente à Satisfação com o peso, Estima corporal e Preocupação com a aparência. Dos 100 elementos seleccionados para este estudo, 49 acederam participar. Deste modo, a amostra é constituída por 16 participantes do sexo masculino e 33 do feminino, com uma média de idades de 24,3 anos de idade. Relativamente às habilitações literárias, 24 indivíduos são licenciados (7 em Psicologia, 4 em Direito, 4 em Economia, 4 em Ciências do Desporto e 9 distribuem-se por outras licenciaturas como Fisioterapia, Jornalismo, Educação de infância), 2 têm bacharelato (curso técnico de Análises Clínicas), 11 frequentam o ensino universitário e 2 são estudantes do ensino secundário. Quanto à situação profissional, 34 indivíduos encontram-se empregados, 3 são desempregados e 13 são estudantes. O estado civil é representado por 44 solteiros e 5 casados, não havendo participantes em união de facto ou divorciados.

Considerámos pertinente também avaliar o Índice de Massa Corporal (IMC; peso/ altura ${ }^{2}$ ) para termos a relação entre a percepção do peso por parte dos participantes e o peso "real" classificado em três categorias³. Contudo, só foi possível ter acesso a esta informação por parte de 34 participantes. Assim sendo, constatámos que, dos 34 participantes classificados, 41,2\% ( $n=14)$ pertenciam ao grupo "magro" de IMC, $44,1 \%(n=15)$ tinham peso normal e $14,7 \%$ desta (sub)amostra apresentava excesso de peso $(n=5)$.

3 Considerámos a categoria dos sujeitos magros (IMC < 20), com peso normal (IMC 20 a 24,9) e com excesso de peso (IMC 25 a 29,9). Não existem participantes nas restantes categorias de IMC (obeso e peso mórbido) na nossa amostra. 


\title{
Procedimento(s)
}

\section{Recrutamento e realização das entrevistas}

Os participantes foram contactados pelas entrevistadoras, por via telefónica, tendo sido realizadas, no máximo, 5 tentativas de contacto, a horas do dia e dias diferentes. Nos contactos telefónicos, era relembrado aos indivíduos que tinham participado num estudo há 6 anos, que tinham preenchido uns questionários na instituição de ensino que frequentavam e que, na altura, Ihes tinha sido dito que alguns participantes poderiam ser novamente contactados para uma segunda fase do estudo. Eram informados que tinham sido seleccionados aleatoriamente para esta fase e que o mesmo estudo se debruçava, no momento, na realização de entrevistas, que pretendiam perceber como as pessoas se relacionavam com o seu corpo e como isso influenciava o seu dia-a-dia e as relações com os outros. Os participantes foram ainda informados do carácter confidencial das entrevistas, da duração média das mesmas e do local da sua realização. As entrevistas tiveram uma duração média de 1hзom.

\begin{abstract}
A análise dos dados
As entrevistas foram transcritas na íntegra, não tendo sido excluída nenhuma informação, tendo sido, contudo, omitidos quaisquer dados que pudessem identificar o entrevistado. Este processo foi iniciado concomitantemente à recolha dos dados. No sentido de facilitar a análise da imensidão dos dados recolhidos, foi utilizado o OSR NUD*IST N6.o (Qualitative Solutions and research Pty Ltd - Non-numerical, Unstructured, Data: Indexing, Searching and Theorising) que permite a análise de dados pouco estruturados.
\end{abstract}

\section{Resultados}

A grande questão teórica neste estudo, diz respeito à exploração dos processos desenvolvimentais no contexto da construção da imagem corporal, com uma ênfase especial na compreensão das experiências corporais na infância, adolescência e adultez no contexto da relação parental. O contexto relacional da família no qual estas experiências ocorrem, será um factor central, neste estudo, para a compreensão da corporeidade.

Consideramos então esta questão de investigação, abordando progressivamente cada uma das restantes questões que dela decorreram, tendo como linha orientadora o eixo temporal (dividido em três etapas desenvolvimentais: infância, adolescência, actualidade ou jovem adultez). Neste sentido foram abordados a 
qualidade da relação parental e vivência emocional do toque, a descoberta da sexualidade e a vivência da nudez na família desde a infância até ao momento da entrevista. Algumas questões do guião da entrevista são:

- (na infância) Como era a sua relação com os seus pais?

- Como é que era a sua família em termos de manifestações de afecto? Como se sentia?

- Que recordações tem acerca das brincadeiras que tinha? Com quem brincava mais? Que tipo de brincadeiras gostava mais? Os seus pais brincavam consigo? Como eram essas brincadeiras? Com quem gostava de brincar mais e porquê? Havia abraços, carícias, beijinhos? E gostava? Como se sentia?

- Quem o(a) deitava? Quem Ihe dava banho? Quem o (a) ajudava a vestir? Como eram esses momentos para si?

- Quem é que cuidava de si quando estava doente? E a quem recorria quando tinha medos?

- De que forma é que a família lidava com questões como o vestir, os banhos, a nudez?

- Lembra-se quando começou a ter vergonha de mostrar o seu corpo?

- Lembra-se de ter curiosidade relativamente ao seu corpo? E ao dos outros?

- É por volta desta fase da vida que as crianças começam a explorar o seu corpo e o dos outros, lembra-se disso? (ex. Brincar aos médicos, espreitar nas casas de banho, etc.) Passou-se consigo? Como foi essa vivência? Com quem brincava?

- Lembra-se quando descobriu o corpo como fonte de prazer? A descoberta da sua sexualidade?

- Elembra-se das suas primeiras questões relativamente à sexualidade? (como nascem os bebés, como se fazem os bebés...), quem é que respondia a essas questões ou falava consigo sobre isso?

- Alguma coisa mudou lá em casa com o seu crescimento? As brincadeiras, os abraços, a privacidade? Como é que era a relação com os seus pais nessa altura?

- Que importância se dá na sua família às questões da "aparência", das "regras da boa educação", à ênfase que o corpo tem na vida das pessoas? Falam acerca destas questões em casa?

Iremos apresentar e discutir, de seguida, alguns dos principais temas que emergiram destas questões, nomeadamente, o papel do toque na vivência corporal, as brincadeiras e cuidados parentais, a vivência da sexualidade e da nudez. Tentaremos ilustrar esta análise com algumas citações dos nossos participantes (identificadas com o número do documento e sexo a que pertence). 


\section{As memórias do toque na vivência corporal}

Um dos temas que emergiu do discurso dos participantes foi a qualidade do contacto físico entre os participantes e os significativos e a eventual relação entre esta valência corporal e a vivência do corpo ao longo do desenvolvimento. De facto, sabemos que o contacto físico, para além de ser um tocar intencional entre duas ou mais pessoas, é uma forma de comunicação, é-se eminentemente em relação aos outros. Observámos que, essencialmente na infância e relativamente à relação parental, quando as trocas de afecto através do contacto físico são mais frequentes, tanto rapazes como raparigas descreveram pais que manifestavam o seu afecto de forma física, através do toque, sendo estas experiências valorizadas desde a infância e por ambos os sexos. Incluímos nestas experiências as manifestações físicas de afecto, os cuidados e as brincadeiras (enfatizando aquelas que se caracterizavam por contacto físico) com ambos os progenitores.

De uma forma geral, foi interessante constatar a descrição da figura paterna de forma igualmente afectuosa em termos de toque, com 13 participantes $(26,5 \%$, dos quais 10 eram do sexo feminino e 3 do sexo masculino) a referirem a inexistência de manifestações físicas de afecto por parte do pai com eles na infância. Por seu lado, 16 entrevistados (32,7\%) mencionam que algumas vezes o pai era fisicamente carinhoso (8 raparigas (50\%) e 8 rapazes (24\%)] e outros 16 participantes $(32,7 \%)$ descrevem um pai frequentemente afectuoso [destes 12 são raparigas (36\%) e 4 são rapazes $(25 \%)]$.

"Sempre houve muito carinho, sempre. A minha mãe ainda hoje me dá colo, que não pode comigo, o meu pai também, brincamos muito com ele, brinco muito com ele. Pronto, esse tipo de ligação, digamos que quase perfeita." (doc 1162 , rapaz)

"Os meus pais são muito afectuosos...também eu costumava ir, ao sábado de manhã, lembro-me perfeitamente, que costumava ir para a cama do meu pai e da minha mãe, às vezes, até dormia lá!" (doc 207, rapariga)

Particularmente, foi importante verificar como referem de forma diferenciada a relação que mantinham com a figura materna e paterna, salientando-se as representações que foram construindo acerca das manifestações de carinho, ou ausência destas, sobretudo no que diz respeito à relação paterna, descrita como menos afectuosa fisicamente. Saliente-se, contudo, a forma como os participantes processam estas vivências, nomeadamente a percepção de que quantidade não é necessariamente qualidade, de que, apesar de não terem um pai fisicamente explícito na forma como manifesta o seu afecto, isso não significa necessariamente que este não seja carinhoso, percepcionando diversas formas de ser afectuoso, como ilustra um participante:

"Os meus pais davam muitos mimos, mais a minha mãe que o meu pai, quero dizer, o meu pai também dava mas de maneira diferente. A minha mãe era mais 
explícita, era capaz, ainda é, muito, de pegar em nós, abraçar, dar beijinhos, dizer coisas do tipo "minha princesa" ...o meu pai também me dava colo, beijinhos, abraços,mas..., não dizia essas coisas assim, dizia de maneira diferente. Eu acho que ele não lida tão bem assim com essas coisas dos afectos, das emoções e... não lida muito bem com isso. Nunca vi o meu pai a chorar nem nada do género e a minha mãe chora muitas vezes (risos). “ (doc 197, rapariga)

Por outro lado, a diminuição da frequência do toque, com o início da adolescência, é, naturalmente, substituído pela verbalização. Este distanciamento físico dos pais traduz a sua maior autonomia e individualização, o que é desejável. Contudo, o contacto físico continua a existir, muitas vezes como forma de exteriorização de sentimentos (alegria, tristeza, dor, se algo corre mal, em situações de ameaça, etc.), assumindo um valor protector em momentos de grande fragilidade (ex. doença). Curiosamente, esta diminuição do toque na adolescência não foi evidenciada pela nossa amostra, com apenas alguns entrevistados a relatarem uma diminuição (natural) desse contacto. Por seu lado, quando se atende a especificidades de género dos participantes e dos próprios progenitores, não foram encontradas diferenças significativas em termos de discurso, com os filhos e filhas a percepcionarem da mesma forma as manifestações de carinho por parte do pai ou da mãe na adolescência. Todavia, encontramos mais rapazes a revelarem uma diminuição do contacto físico, especialmente com a figura paterna, comparativamente com as raparigas. De facto, esta nova dimensão do contacto físico, particularmente entre pai-filha ou pai-filho, poderá ser explicada pelo próprio desenvolvimento corporal e sexual dos filhos, que se torna visível e poderá ser mais ameaçador para o pai, do que seria em fases anteriores, em que esta conotação sexual não existia (Flaake, 2005), além do próprio afastamento natural por parte dos filhos. Algumas entrevistas indicam que uma das estratégias dos pais lidarem, particularmente, com as mudanças físicas das filhas consiste no uso de comentários brincalhões acerca das transformações corporais das filhas - uma abordagem humorística, divertida da sua puberdade, entendida como um elemento de comunicação relaxada em família - o que nem sempre é experienciado da melhor forma pelas filhas que, nalguns casos, revelam embaraço ou revolta aquando destas situações.

Assim, embora saibamos que os estereótipos de género podem desempenhar um importante papel na gestão e expectativas do toque, essa diferença parece não ser muito marcante nesta amostra de participantes. Com efeito, não se verificaram muitas divergências na forma como os pais tocam os filhos (rapazes e raparigas), evidenciando-se esta diferença apenas na infância, com as filhas a descreverem ambos os pais como mais carinhosos do que os filhos. De qualquer forma, de uma forma geral, as histórias narradas parecem indicar que rapazes e raparigas começam a ser socializados de forma a aceitarem e esperarem mais o toque. 
Destacamos ainda o facto de que a vivência corporal positiva no jovem adulto e a sua atitude positiva perante o toque e proximidade física esta rem associados a relatos de experiências físicas afectivas com os pais desde a infância, confirmando os estudos de Fromme e colaboradores (1989) e de Gupta e Schork (1995). No entanto, se tivermos em conta o género do progenitor, verificámos que a mãe foi descrita como mais afectuosa do que o pai, embora alguns inquiridos descrevessem um pai bastante afectuoso. Portanto, parece assistir-se a uma tendência para os afectos deixarem de estar mais associados à figura materna, havendo uma grande valorização das manifestações físicas de carinho também por parte da figura paterna. Mais, será importante referir que os participantes terão percepcionado formas diferentes de pai e mãe expressarem os afectos, pois, embora pudessem descrever um pai mais distante em termos físicos, não deixaram de salientar que tinham um pai carinhoso e presente.

Além disso, verificámos que os filhos (rapazes) valorizavam, de igual forma, as manifestações de carinho (os abraços, beijinhos, os mimos), comparativamente às raparigas, parecendo indicar que na nossa sociedade os rapazes também estão a ser socializados a valorizarem, tal como as raparigas, o contacto físico, uma mudança que começa no seio do contexto familiar. Isto ajuda a entender por que é que as diferenças de género neste âmbito estão a ficar mais ténues. Mas, se esta ausência de diferenças de género foi descrita em circunstâncias relacionais de maior intimidade (esfera mais "privada"), o mesmo não parece transparecer dos discursos analisados quando se tem em conta uma vertente mais "pública" das relações interpessoais, isto é, homens e mulheres terão comportamentos mais diferenciados. Com efeito, as mulheres parecem mais inclinadas a tocarem, a sentirem-se mais confortáveis com o toque, tendo mais dificuldade em separar a intimidade física da verbal, do que os homens. Assim, à medida que as crianças entram na adolescência, o desejo de proximidade física e do toque orienta-se frequentemente para os pares. As raparigas tocam-se mais entre elas, por comparação com os rapazes, o que foi evidenciado nos discursos destes jovens (embora disseminado noutras respostas mais concretas na entrevista).

As três funções da vinculação - a manutenção da proximidade, porto seguro e base segura - são lentamente transferidas dos pais para os pares e par amoroso à medida que os adolescentes entram na adultez (Hazan \& Shaver, 1994). Todavia, como já salientamos, a importância da vinculação aos pais não parece estar em causa, estando mesmo relacionada com a construção de relações amorosas de qualidade (S. Barbosa \& Costa, 2001; Matos \& Costa, 2001) ou com a vivência do toque nessas relações (S.Barbosa \& Costa, 2001). Verificámos, desta forma, que, de uma forma geral, à medida que os participantes foram crescendo, o contacto físico com os pais foi-se mantendo, sendo relatado nos discursos dos participantes (particularmente nas raparigas) o colo ou o beijo na cara, por exemplo, como mani- 
festações comuns de carinho na relação pais-filhos. Por seu lado, na relação com os pares, essencialmente na romântica, o contacto físico tende a aumentar, culminando na intimidade sexual, a que Ashley Montagu (1986) no seu livro Touching chamou de "a mais profunda linguagem do toque" (p.204). Voltaremos a este ponto mais à frente nesta discussão aquando da contextualização do corpo na relação romântica.

Desta forma, o contacto físico deve ser adequado à idade, ao contexto cultural e histórico e ao objectivo. Curiosamente, esta necessidade de toque e contacto físico poderá ser atendida também através do contacto com um animal doméstico, por exemplo. Esta realidade foi ilustrada por uma participante que associa um aumento do toque e da afectividade entre os familiares desde que adquiriram um cão, ou por outra com a presença de um gato, verbalizando que o contacto com o animal fez com que também eles se aproximassem fisicamente. Parece indicar que a oportunidade de expressar afecto por um animal poderá levar a que as pessoas se tornem mais expressivas fisicamente com as pessoas também.

Assim, o que importa reter é que o contacto físico, presente e adequado, é determinante para a formação da vinculação entre pais e filhos e, por sua vez, esta é determinante no desenvolvimento emocional e afectivo, no "ensinar" a linguagem das emoções. Efectivamente, como vimos, a qualidade das relações afectivas, operacionalizada também através das manifestações físicas de carinho e do toque, é transversal às narrativas apresentadas por este grupo de participantes, aparecendo em lugar de destaque em todas as etapas desenvolvimentais abordadas, independentemente de se ser rapaz ou rapariga. De facto, a afectividade percepcionada na relação parental na infância não parece diminuir durante a adolescência e juventude dos participantes, sugerindo que a qualidade da relação pais-filhos se prolonga desde a infância e contribui para o posterior bem-estar dos filhos. Finalmente, será necessário continuarmos a compreender o toque no seu habitat natural, oferecido, recebido e, idealmente, mutuamente apreciado no contexto das relações sociais, e de que forma a necessidade de toque é uma componente básica do desenvolvimento humano, nomeadamente na construção do ser humano enquanto ser corporal - o corpo não é algo que se tem, mas algo que se é.

\section{As brincadeiras e cuidados parentais}

Além das manifestações físicas de afecto, os momentos lúdicos e de cuidados com o bebé podem também ser fortes oportunidades de relacionamento e de vivência do toque. É verdade que nos deparamos com muitos pais que, por estarem muito preocupados com o futuro dos seus filhos, nomeadamente em termos profissionais, supervalorizam a aprendizagem da leitura e da escrita, dos trabalhos 
escolares, suprimindo o tempo do lúdico na vida da criança. Na verdade brincar é uma actividade universal, a criança brinca para se conhecer a si própria e aos outros, vai explorando o seu corpo, o espaço, aprendendo as normas sociais, os hábitos, conhecendo os objectos, desenvolvendo a linguagem e a narrativa, além do seu imaginário. Ademais, quando a criança brinca com os outros, em contacto com o outro, aprende a controlar os seus impulsos e a respeitar o espaço do outro, sendo uma experiência de socialização enriquecedora. Nesta mesma direcção, a contribuição do adulto será primordial, quando reconhece o valor e o lugar da brincadeira. Com efeito, os discursos que escutamos reforçam a importância da brincadeira como um instrumento privilegiado de expressão para os participantes, através dos quais se podem vivenciar momentos de qualidade, tão valorizados por pais e filhos, funcionando como um mecanismo fundamental de comunicação (táctil ou não) e de facilitador de uma experiência corporal positiva. Esta relevância aparece ilustrada aquando da análise das variáveis mais associadas à vivência corporal ao longo do desenvolvimento, com a variável brincadeiras com o pai ou com a mãe na infância associada a uma avaliação mais positiva do corpo, independentemente da etapa de desenvolvimento a ser estudada.

Na generalidade, a maternidade ou paternidade não serão assim tão diferentes, no entanto, quando comparadas, poderão ter condutas distintas, parecendo intervir e interagir de forma diferenciada na socialização de rapazes e raparigas (larson \& Richards, 1994). A parentalidade também tem variado em resposta às mudanças das expectativas e construções que as pessoas têm em relação ao que é ser mãe e ser pai. Embora se continue a constatar um maior envolvimento dos pais no trabalho e das mães nas tarefas domésticas e cuidados dos filhos, estas têm vindo a convergir. De facto, tal como tem vindo a ser encontrado noutros estudos, verificámos que o pai assume um papel mais saliente na vertente lúdica com os filhos. Embora as diferenças não sejam consideráveis, um maior número de participantes referiu a figura paterna como aquela que brincava com eles às vezes $(n=18)$ ou bastantes vezes $(n=7)$, comparativamente à mãe $(n=16$ e $n=4$, respectivamente). Dois exemplos:

"Sem ser brincadeiras específicas, recordo-me de momentos que estávamos juntos, principalmente de manhã, aos fins de semanas, em que estávamos com os meus pais a brincar. A fazer tipo toquinhas, e depois punha os joelhos em cima e depois baixava os joelhos, o meu pai e eu caía na cama, brincadeiras dessas." (doc 422, rapariga)

"Ah, eu brincava com o meu pai, bastante, íamos para um parque que havia perto de minha casa, recordo-me que íamos muitas vezes para a praia, uma infância muito bem acompanhada pelos meus pais, jogava à bola, brincava com carrinhos, com os meus pais a acompanhar-me. Lembro-me bastante disso." (doc 1162, rapaz) 
Contudo, as diferenças não são consideráveis se ponderarmos o "brincar por vezes" com os filhos, o que reforça, mais uma vez o enfraquecimento diferenciado dos papéis parentais. Ademais, será importante considerar o facto de que estes relatos corresponderem a experiências vivenciadas há cerca de 20 anos atrás (os entrevistados são agora jovens adultos), o que nos levará a questionar de que forma é que estas diferenças se manteriam se as entrevistas fossem realizadas tendo em conta a parentalidade nos dias de hoje, isto é, daqui a 20 anos como é que os adolescentes falarão acerca destes pais?

Vários exemplos, como pegar nos filhos e andar à roda, andar às cavalitas, envolvem mais força física, o que poderá levar os filhos a criarem expectativas de que determinadas brincadeiras estarão mais associadas ao pai. Através deste papel de "companheiro de brincadeira" o pai pode encorajar o sentido de autonomia e independência dos filhos, além da brincadeira servir também para informalmente comunicarem acerca de assuntos mais sérios. Parece importante que os pais utilizem estes momentos de lazer para conversarem com os filhos e construírem laços emocionais com eles, não substituindo o contacto físico apenas pela interacção verbal. Este modelo, aparentemente distante, poderá ser importante na fase de separação característica da adolescência, uma proximidade suficiente, que respeitará e permitirá a separação e individuação do adolescente. Efectivamente, embora as actividades a dois, entre pais e filhos, aproximem os corpos, eles são vividos como separados, assim, estas actividades poderão propiciar o sentido de separação dos filhos (Shulman \& Seiffge-Krenke, 1997). Esta crescente consciência de que os corpos são separados, irá evidenciar-se com a consciência das diferenças sexuais. E foi interessante perceber que a maioria dos adolescentes, apesar de descreverem um pai que passa menos tempo com eles, por razões profissionais, percebem-no como uma figura de apoio. De facto, destacámos que, do ponto de vista desenvolvimental e da teoria da vinculação, ambas as figuras parentais desempenham um papel importante na construção de um sentido interno de segurança dos filhos, apesar de cada um o poder fazer de forma única e diferenciada, mas complementar. Nesta perspectiva da ecologia da parentalidade, a investigação tem sugerido que o pai poderá ter um papel saliente ao nível da exploração no desenvolvimento da vinculação, assim como na transmissão de segurança durante as actividades de exploração e de brincadeira, complementando, desta forma, o papel de base-segura da mãe como figura de vinculação (Grossmann, Grossmann, Fremmer-Bombik, Kindler, Scheuerer-Englisch, \& Zimmermann, 2002). Todavia, este ponto de vista não implica que ambas as figuras parentais não possam desempenhar os dois papéis, o que acontece frequentemente. Apenas gostaríamos de enfatizar a perspectiva dos papéis parentais à luz do equilíbrio balanceado entre vinculação-exploração no contexto das relações familiares. 


\section{Prestação de cuidados}

Um dos importantes papéis dos pais tem a ver com a prestação de cuidados aos filhos, na qual o toque e o contacto físico são primordiais. Assim, as necessidades básicas de higiene, o dar banho, o vestir, deitar, dar de comer ou o cuidar quando o filho está doente são também oportunidades únicas para manifestar amor e carinho através do corpo. Além destas situações os cuidados "psicológicos" como a empatia, o respeito, fazer a criança sentir-se amada são também fundamentais. De uma forma geral os resultados apontam, como seria esperado, para a descrição da figura materna como a mais cuidadora; para a maioria dos participantes era a mãe que os vestia ( $n=45,91,8 \%)$, Ihes dava banho $(n=44,89,8 \%)$, cuidava deles quando estavam doentes $(n=40,81,6 \%)$ e era a ela que recorriam quando tinham medo ( $n=35,71,4 \%$ ). No entanto, algumas destas tarefas eram também partilhadas com a figura paterna que, embora com menos frequência, na maioria das vezes devido à sua ausência por motivos profissionais, quando estava presente dividia estes momentos com a mãe, essencialmente no dar banho e cuidar na doença dos filhos. Assim, 12 (24,5\%) participantes referem que o pai os vestia, 17 $(34,7 \%)$ que o pai também Ihes dava banho, 16 (32,7\%) que cuidava deles quando estavam doentes e $21(42,9 \%)$ recorriam ao pai quando tinham medos na infância. Independentemente da figura parental que prestava esses cuidados, estes momentos foram sempre descritos de forma positiva. Foi interessante verificar que os participantes justificaram a menor frequência dos cuidados por parte do pai por motivos profissionais, estando a mãe mais presente e, portanto, mais disponivel para estas tarefas.

Assim, reforçou-se a hipótese da figura materna mais associada à família, a comportamentos de cuidadora e de afecto, enquanto que a figura paterna é mais ligada ao mercado de trabalho, a interacções de afiliação e brincadeiras (Geider, 1996; Kazura, 2007; Poeschl, 2000, 2001/2002; Poeschl \& Pinto, 2001/2002; Poeschl \& Serôdio, 1998), embora seja de salientar que estas diferenças possam estar cada vez mais esbatidas na nossa sociedade, o que foi reforçado por esta amostra de participantes. Além disso, a natureza única destas relações poderá ser enquadrada numa leitura ecológica da vinculação, destacando-se a complementaridade e significado da relação de vinculação com cada uma das figuras parentais.

\section{A vivência da sexualidade}

A vivência da sexualidade, como meio de expressão dos afectos, é uma maneira de cada pessoa se descobrir a si e aos outros. A educação sexual é inerente à vida e começa desde cedo, diz respeito aos pequenos hábitos diários, no mudar as fraldas, no dar banho, no deitar os filhos, nos afectos e carícias, nos olhares e 
em aspectos tão vastos como as opiniões e críticas acerca dos acontecimentos e valores do mundo. Assim, a forma como cada um vivencia a sua sexualidade é transmitido, frequentemente, de forma implícita - não se fala, mas vivem-se essas sensações e referências, e foram estas vivências que tentámos explorar.

Como constatámos, mesmo sabendo que as crianças e jovens têm outras fontes de informação, como a escola, os amigos ou os media, o papel da família é sempre distinto, dada a tonalidade emocional e afectiva com que as situações são experienciadas. Um grande número de participantes refere que a sexualidade era abordada em família, mas com alguma reserva $(n=17,34,7 \%$, dos quais $31,3 \%$ são rapazes e $36,4 \%$ raparigas), referindo que se sentiam confortáveis em discutir e abordar com os pais as primeiras dúvidas acerca da sexualidade (ex. "de onde vêm os bebés?", “O que é o sexo?", "Porque é que somos diferentes?”). Todavia, $20 \%(n=10)$ dos participantes mencionam que não se falava de sexualidade em casa (dos quais 7 são raparigas e 3 são rapazes) e apenas $9(18,4 \%)$ participantes refere que se falava com bastante naturalidade de sexualidade em família (7 do sexo feminino e 2 do sexo masculino):

“... Foi só mais tarde, na escola, que eu fui aprendendo. Mas nunca, com os meus pais, nunca houve assim muita conversa sobre isso. Sei que foi natural, sempre que tinha alguma dúvida perguntava e alguém me explicava na escola." (doc 1219, rapaz)

Relativamente poucos participantes se lembravam das suas primeiras curiosidades ligadas à sexualidade (ex. curiosidades acerca das diferenças anatómicas entre homens e mulheres, a sua própria origem), provavelmente porque estas questões foram surgindo em idades muito precoces (por volta dos 3, 4 anos de idade). Paralelamente a estas dúvidas e curiosidades surge também a exploração do próprio corpo, tentando conhecer e promover os sentimentos que ele produz, a fase do reconhecimento do seu sexo, do toque e da observação. Surgem então as brincadeiras que implicam o toque - o brincar aos médicos e doentes, aos pais e às mães. Estes jogos e brincadeiras, já relembrados por um maior número de participantes (mais por raparigas do que por rapazes), permitem a comparação dos seus órgãos com os dos amigos e dos adultos. Será aqui que provavelmente se inicia a associação entre sensações sexuais e órgãos genitais.

"E lembro-me também de brincar aos médicos (risos). Eu lembro-me de uma vez em particular que fomos para casa de uma prima minha que vive mesmo ao lado da minha avó, ainda hoje vive, e então ela tinha um irmão mais novo, mais novo cinco anos. E então nós fizemos uma cabaninha e aquele era o consultório do médico. E depois cada um era o médico à vez. Estávamos lá, nós tirávamos a roupa toda, e depois fazíamos de conta que estávamos a auscultar e coisas assim. Mas isso foi só uma vez ou outra." (doc 1196, rapariga) 
Os restantes descrevem estas vivências como "nada de especial" ou "não me lembro muito disso ter acontecido" e 8 participantes não sabem ou não responderam à questão. Por seu lado, o facto das entrevistadoras serem do sexo feminino e de idades próximas, poderá ter inibido os rapazes a falarem destas experiências.

74 Mais tarde, na idade escolar, verificámos que, para muitos, são vivenciadas grandes mudanças na vida da criança. Com a entrada na escola surgem novos companheiros, outros adultos, importantes aprendizagens e novas exigências pessoais e sociais, descritas de forma positiva pelos participantes. Com a chegada da puberdade constatámos que há pais que alteram as suas atitudes, deixando, por exemplo, de sentar o filho ou a filha ao colo, de os acariciar enquanto conversavam ou viam televisão, como tantas vezes acontecia até então. Assim, relativamente ao toque/ manifestações de carinho na adolescência, parece haver uma tendência a manterem-se as manifestações de carinho que se experienciaram na infância $(42,9 \%)$ ou então a diminuírem (28,6\%). Este comportamento, modificado (segundo alguns participantes) por falta de à vontade dos pais, ou deles próprios, agora que já são "uma mulher" ou "um homem", poderá causar alguma perplexidade ou tristeza no jovem ou nos próprios pais (essencialmente na relação pai-filha) (Moita \& Santos, 2007). Estas situações, contudo, não parecem reflectir os discursos dos nossos participantes, que se referiram a estas mudanças com naturalidade. Isto é, o envolvimento afectivo dos pais com os filhos não parece ser globalmente afectado pelo desenvolvimento pubertário (Ogletree, Jones, \& Coyl, 2002), apesar da eventual menor proximidade física percebida por alguns. Aliás, estas mudanças de comportamento são referidas por todos como naturais, tendo em conta os novos interesses e contextos relacionais que, entretanto, foram sendo tão ou mais valorizados, essencialmente pelos rapazes.

“Hã...foi decrescendo (a frequência de manifestações de carinho). Foi decrescendo. Talvez se calhar até por minha vontade, eu não estava tão à vontade para isso queria era computador, livros, passeio, jogar à bola, mas por vontade minha."(doc 1126, rapaz).

Verificámos que, embora nos contextos interpessoais mais públicos o toque possa diferir em termos de género, sendo as mulheres aquelas que mais são associadas ao toque e ao serem tocadas, o toque na esfera mais privada e familiar parece não diferir pelo facto de ser filho ou filha ou de ser o pai ou a mãe a manifestarem de forma física o afecto. O que parece evidenciar-se nos discursos dos participantes é que com a idade e, fundamentalmente, na adolescência, o toque não é encarado com um tabu, principalmente nas raparigas. Assim, embora alguns participantes referissem que nesta etapa das suas vidas começaram a não se sentir tão confortáveis com as demonstrações físicas de carinho parental, a terem vergonha, a sentirem a necessidade de se sentirem mais independentes dos pais ou a procurarem esse conforto no contexto de pares (o que caracteriza precisamente o 
processo de separação e individuação nesta fase de desenvolvimento), na verdade, em aproximadamente $43 \%$ dos participantes esta proximidade física manteve-se.

Também verificámos que a possibilidade e o diálogo mais ou menos aberto acerca da sexualidade na adolescência, a partilha com os pais dos seus sentimentos, terá a ver com as oportunidades de diálogo que foram sendo desenvolvidas desde a infância, com a aceitação e entendimento das diferenças de valores e atitudes desde cedo. Foi importante constatar que esta comunicação aberta acerca da sexualidade e do desenvolvimento pubertário está também associada a discursos e narrativas positivas acerca do corpo e imagem corporal ao longo da vida, tanto para o sexo feminino como para o masculino. Assim, um ambiente familiar que facilite a comunicação, uma abordagem serena destas questões e a criação de espaços adequados para se poder perguntar e para se poder responder serão fundamentais para uma vivência igualmente serena e saudável do corpo e da sua sexualidade.

\section{A vivência da nudez}

A naturalidade com que é vivenciada a nudez desde a infância parece ser, por seu lado, um outro aspecto a ressalvar na construção de uma imagem corporal positiva e saudável. Neste contexto, o facto dos participantes terem descrito uma vivência saudável do corpo, através da forma como a nudez era vivida em família ou na relação parental, parece transpor-se para a vivência salutar do corpo em sociedade. Destacam-se então os primeiros contactos dos indivíduos com o corpo dos outros, verificando-se uma associação entre o à-vontade no seu próprio corpo e uma experiência mais positiva em termos de desenvolvimento da imagem corporal.

Ao longo dos vários discursos, fomo-nos apercebendo de um continuum relativamente àquilo que uns participantes consideravam a vivência de uma nudez natural ou à-vontade. Na verdade, o "andar sem roupa à frente dos filhos ou tomar banho com eles" parece ser uma questão que continua a causar algumas dúvidas e apreensões aos pais. Todavia, como constatámos, a vivência destas situações não é nada de problemático quando os pais se sentem à vontade e vivem com naturalidade e bom-senso a sexualidade (respeitando a sua privacidade e a dos seus filhos). Comportando-se de tal forma, eles parecem desenvolver na criança a noção do corpo e da sexualidade, sem alusão à censura e à vergonha. Contudo, se pelo contrário, ficam constrangidos, devem evitar essa situação, respeitando o seu limite interno, caso contrário poder-se-á criar um clima artificial, o que será percebido pelos filhos (o que foi ilustrado por algumas raparigas, que descreveram de forma negativa a forma como os pais lidavam a nudez). De facto, o comporta- 
mento dos pais configura o que o nu representa, as crianças conseguem captar a linguagem não verbal do corpo e, se percebem um sinal de apreensão por parte dos pais, tenderão a encarar a nudez como algo feio ou proibido. Além disso, é natural que a criança sinta curiosidade perante a nudez do outro, despertando as primeiras perguntas acerca da sexualidade, para as quais os pais se devem ir preparando com a mesma naturalidade e clareza. Com efeito, os momentos do banho e do vestir (ou despir), podem ser momentos propícios que os pais usam para ensinar os nomes das diversas partes do corpo, por exemplo, além de serem momentos importantes de vivência corporal em família (através do olhar e do toque dos pais), o que fará com que os filhos desenvolvam, ou não, um sentimento de conforto com o seu próprio corpo.

Vimos que cada família tem os seus hábitos e modos diferentes de viver a sua própria nudez, neste estudo encontrámos pais mais ou menos conservadores relativamente à forma de encarar o nu, desde aqueles que o cercam de tabus até os que o tratam com naturalidade (o que foi retratado pela maioria dos nossos participantes). No entanto, verificámos também que alguns participantes se sentiam constrangidos quando se despiam diante dos pais, trancando-se no quarto ou na casa de banho, particularmente a partir do começo da puberdade e, particularmente, no sexo feminino (perante o pai), que descrevem ter começado a sentir vergonha nesta fase de desenvolvimento, o que descrevem como uma reacção natural, sendo respeitada pelos pais. De facto, a puberdade parece ser um marco na relação pai-filha - esta começa a ser mulher - as manifestações de carinho tendem a diminuir, a vergonha e o aumento do desejo de privacidade, essencialmente, em relação à figura paterna são evidenciados.

Assim, relativamente à questão "Houve mudanças na familia com o seu crescimento, quanto à vivência da nudez/privacidade?", verificámos que grande parte dos inquiridos respondeu que sim, que houve mudanças a esse nível, mas vividas de forma positiva, natural, alegando a sua maior necessidade de privacidade e do seu próprio espaço, sendo o quarto o seu espaço "privativo" por excelência (ver exemplo).

\footnotetext{
"Eu lembro-me que o meu irmão, dormia eu e o meu irmão no mesmo quarto até que houve uma altura, já não sei exactamente quando mas aí por volta, deve ter sido, dos 13, 14 anos em que o meu irmão mudou-se para outro quarto. Assim agradou um e outro não é? Porque ele também ia iniciar a sua fase de transformação e eu já estava nessa fase ...eu lembro-me que nessa altura já me sentia mais constrangido, quando estava a tomar banho e entrava o meu pai ou a minha mãe. E depois, "Vamos pôr uma chave na porta?".Mas era no meu quarto que tinha a minha privacidade, era o meu espaço, eu gostava de estar sozinho, mas nunca houve problema de maior" (doc 1214).
} 
No entanto, através dos discursos que analisámos o facto de terem tido uma vivência da nudez mais ou menos positiva ou "natural" não será central para a forma como as raparigas se sentem com o seu corpo ao longo do desenvolvimento. Vimos, por exemplo, que um terço das raparigas que descreve o seu corpo de forma parcialmente negativa (demonstrando insatisfação com alguma parte do seu corpo) relata uma nudez vivida com naturalidade.

Por seu lado, foi interessante verificar que a relação entre vivência corporal e nudez foi evidenciada pelo sexo masculino e nas várias etapas de desenvolvimento referenciadas. Com efeito, mesmo os rapazes que descreveram de forma negativa o seu corpo, revelaram lidar com a nudez com bastante naturalidade desde a infância, aliás, nenhum descreve uma vivência negativa da nudez. Ademais, verificou-se que mais de um quarto dos participantes com discursos positivos acerca do seu corpo, também descrevem de forma muito positiva ("à vontade") a vivência da nudez no contexto familiar. Este facto poderá revelar que, de facto, a nudez tem um peso diferenciado para rapazes e raparigas, tendo sido estas socializadas a recatar mais o seu corpo, educadas a protegerem a sua intimidade física, o que não é evidenciado nos discursos masculinos, cujo à vontade com o seu corpo e a sua nudez, mesmo perante a mãe (apesar de poder diminuir um pouco com a adolescência), permanece nas várias etapas de desenvolvimento.

\section{Conclusões e implicações}

Uma das principais constatações que podemos retirar deste estudo será, certamente, a de que as narrativas apresentadas nos revelaram que o corpo não é um constructo estático, é flutuante e composto por múltiplos elementos, traduzindo a sua complexidade e contextualidade num determinado tempo e espaço na história de vida. Assim, a experiência do corpo aparece embebida nas experiências de vida de cada sujeito e nas suas percepções acerca dessas vivências, variando à medida que os participantes encontram, criam ou ainda reinterpretam as suas experiências. De facto, não é possivel apagar experiências relacionais/corporais mais negativas que se possam ter vivenciado na infância ou mesmo "contrariar" as poderosas mensagens veiculadas pela cultura e sociedade em que vivemos, mas verificámos que diferentes contextos familiares, que vão variando em termos de intensidade e significado, de acordo com as diferentes etapas de desenvolvimento, podem intensificar ou adversar experiências corporais passadas.

Verificámos que da análise das narrativas ou das suas histórias do corpo a infância e as primeiras interacções (quase exclusivamente corporizadas) poderão ter um papel de destaque no processo de desenvolvimento, não podemos deixar de assumir que 
estas vivências serão depois actualizadas/flexibilizadas de acordo com a qualidade das relações que o sujeito for construindo. $\mathrm{Na}$ verdade, estes dados salientam a importância das experiências vivenciadas desde a infância, particularmente a relevância da qualidade das relações afectivas, do toque e da comunicação táctil (experienciada na relação parental através das manifestações físicas de carinho, das brincadeiras, dos cuidados parentais). Efectivamente, apesar de um ligeiro aumento do distanciamento (particularmente o físico) na adolescência, o que será natural nesta fase de desenvolvimento, os pais continuam a ter um importante papel de suporte emocional, e na própria vivência corporal dos seus filhos, ao longo das diversas etapas de vida dos participantes. Além disso, verificámos que, principalmente na infância, pai e mãe desempenham papéis diferenciados, sendo a figura parental mais associada à experiência lúdica e a materna aos cuidados, o que reflectirá a importância das componentes específicas das relações em função das particularidades de género das figuras parentais. Na verdade a definição social do papel de pai tem vindo a sofrer modificações significativas nos últimos tempos, com a reivindicação de uma maior proximidade afectiva assim como dos cuidados básicos das crianças. De qualquer forma, salientamos o facto de que o importante será o significado destas experiências diferenciadas de vinculação no seio familiar para o desenvolvimento de um modelo de si coerente e integrado. Assim, se e como pai e mãe partilharão as duas dimensões da vinculação (base segura e companheiros de exploração) e como é que estas experiências são integradas será um desafio a atender em futuros estudos.

Será necessário dar continuidade à investigação que se tem centrado no papel que a família, os pares ou a relação romântica pode desempenhar na construção da imagem corporal e em diferentes etapas de desenvolvimento. Esperamos que este trabalho se revele motor de estudos nacionais futuros nesta área.

Assim, a teoria da vinculação parece oferecer um enquadramento conceptual importante para o estudo e a compreensão dos processos de construção, não só das relações afectivas, mas do impacto que estas podem ter na construção da imagem corporal. Destacámos a importância dos sinais tácteis como organizadores da qualidade das relações, podendo ser emissores-receptores de aproximação ou afastamento. Aliás, arriscaríamos a afirmar que não existe uma corporeidade simples, mas uma intercorporeidade. No entanto, embora estes resultados tenham sido analisados, particularmente, a partir da influência que os contextos de desenvolvimento poderiam ter na construção da imagem corporal ao longo da vida, acreditamos que as relações sociais e afectivas não só influenciam a forma como o corpo é experienciado, como elas próprias são moldadas pelas próprias experiências corporais. Efectivamente, uma das hipóteses aqui desenvolvida é que experiências precoces como o contacto físico, os momentos de brincadeira, assim como outros processos sociais e interpessoais que estão subjacentes ao desen- 
volvimento de relações de vinculação de segurança, poderão levar à construção de representações pessoais, interpessoais e físicas de não aceitação, o que, consequentemente, poderá levar ao desenvolvimento da insegurança e ansiedade em relações sociais e de intimidade no futuro. Por outro lado, uma imagem corporal negativa, um investimento excessivo no corpo e na aparência numa tentativa de auto-definição, poderão exacerbar também a insegurança e a ansiedade nas relações, particularmente aquelas que são física e emocionalmente mais intimas.

Foi interessante verificar a combinação do corpo a contar e a viver histórias acerca do self. Exploramos de que forma o contar histórias acerca da imagem corporal pode ser uma forma de revelar a história pessoal e social de uma pessoa, através da forma como este vai situando e seleccionando/filtrando os factos que narra, o que escolheu lembrar e contar acerca das suas experiências de vida passadas, é, certamente, um processo interpretativo altamente pessoal e único. E é claro que nenhuma narrativa está terminada, as pessoas e os corpos vão-se construindo e estas histórias estão, seguramente, inacabadas.

Salientamos o facto de que estes dados se baseiam nas mensagens percebidas e percepcionadas pelos participantes, podendo não ser consistentes com as actuais e reais mensagens transmitidas por cada uma das fontes interpessoais consideradas. Seria interessante obtermos os pontos de vista dos contextos significativos que enfatizamos (o discurso do pai e da mãe), complementando as percepções individuais e dando uma leitura mais ecológica dos dados (ver Baker, Whisman, \& Brownell, 2000, por exemplo). Por seu lado, seria interessante alargarmos, num próximo estudo, a análise do papel dos irmãos e avós, para além do papel dos amigos e par romântico no desenvolvimento da vivência corporal.

Por último, tendo em conta os resultados aqui expostos, assim como as implicações que deles podemos tirar, haverá um extenso domínio de intervenção aberto aos Psicólogos e a outros profissionais de saúde a trabalharem nos mais diversos contextos institucionais, além de importantes mensagens aos próprios pais, pares e professores. Como vimos, é importante reconhecer que a vivência corporal emerge a partir das experiências vividas, experiências essas relacionadas com a cultura, a sociedade e os contextos relacionais onde se vive. Assim, o desafio de compreender o corpo pode e deve ser tematizado nos diferentes contextos e práticas educativas, desde a família à escola.

Com efeito, as relações estão em constante mudança e a vivência corporal está imbuída neste processo, e é importante olhar para a forma como as relações são parte de uma experiência corporal. Assim, ao nível do contexto familiar será importante sensibilizar os pais a ajudarem os filhos a gostarem do seu corpo. Como vimos, este processo começa desde muito cedo, podendo os pais proporcionarem memórias corporais de conforto e tranquilidade ao bebé, por exemplo através 
das massagens, das brincadeiras, das carícias. Na infância a modelagem toma um lugar de destaque, pelo que serão fundamental os pais a terem consciência das mensagens, muitas vezes implícitas, que estão a passar. Como é muitos pais podem ensinar os filhos a gostarem do seu corpo se não aprenderam a gostar do deles? Ou se este é vivido como tabu no seio das relações familiares? Na verdade, verificámos que é relevante uma vivência positiva do corpo na família, desde a forma como é modelada a imagem de um corpo saudável (ex. evitar estar constantemente a fazer comentários depreciativos do seu corpo ou do dos outros, a inactividade, má alimentação, atitude perante o envelhecimento), a forma como é experienciada a nudez, as conversas acerca do corpo, das suas mudanças, da sexualidade. É importante os filhos perceberem que existe abertura para questionarem, expressarem as suas dúvidas, angústias, se o quiserem, dando-lhes espaço para se encontrarem e encontrarem o seu corpo em desenvolvimento. Finalmente, trata-se de apoiar os indivíduos na sua tarefa desenvolvimental de definição e aceitação do seu corpo. Será importante perceberem que a avaliação do outro e de si próprio deve ser multidimensional e não assentar quase exclusivamente na aparência, que será um de entre muitos aspectos da sua individualidade.

\section{Referências bibliográficas}

Ainsworth, M. D. S., Blehar, M. C., Waters, E., \& Wall, S. (1978). Patterns of attachment: A psychological study of the strange situation. Hillsdale, New Jersey: Lawrence Erlbaum Associates.

Baker, C. W., Whisman, M. A., \& Brownell, K. D. (2000). Studying intergenerational transmission of eating attitudes and behaviors: Methodological and conceptual questions. Health Psychology, 19, 376-381.

Barbosa, M.R. (2001). A influência da vinculação parental na imagem corporal de adolescentes e jovens. Dissertação de mestrado em Psicologia. Porto: Faculdade de Psicologia e de Ciências da Educação da Universidade do Porto.

Barbosa, M.R. \& Costa, M.E. (2001a). Body image and attachment to parents in Portuguese adolescents. Comunicação apresentada no 8th International Conference of AIFREF. Montreal: Canadá.

Barbosa, M.R. \& Costa, M.E. (2001b). A influência da vinculação aos pais na imagem corporal de adolescentes e jovens. Comunicação apresentada nas VIII Jornadas de Consulta Psicológica de Jovens e Adultos. Porto

Barbosa, M.R. \& Costa, M.E. (2001/2002). A influência da vinculação aos pais na imagem corporal de adolescentes e jovens. Cadernos de Consulta Psicológica, 17/18, 83-94.

Barbosa, M.R. \& Costa, M.E. (2003). Body image and attachment to parents in Portuguese adolescents. In Questions d'éducation familiale dans les années 2000. Collectif sous la direction de E. Palacio-Quintin, J.-M. Bouchard et B. Terrisse (p. 177-192). Montréal: Les Éditions Logiques 
Barbosa, S.R. \& Costa, M.E. (2001). Vinculação amorosa e a experiência emocional do toque em jovens adultos. Comunicação apresentada nas VIII Jornadas de Consulta Psicológica de Jovens e Adultos. Porto.

Benedikt, R., Wertheim, E.H., \& Love, A. (1998). Eating attitudes and weight-loss attempts in female adolescents and their mothers. Journal of Youth and Adolescence, 27, 43-57.

Bowlby, J. (1958). The nature of the child's tie to his mother. International Journal of PsychoAnalysis, 39, 350-373.

Bolwby, J. (1978a). Attachment and Loss, Vol.1. Attachment. Harmondsworth: Penguin Books. (trabalho original publicado em 1969)

Bolwby, J. (1978b). Attachment and Loss, Vol.2. Separation, anxiety and anger. Harmondsworth: Penguin Books. (trabalho original publicado em 1973).

Bolwby, J. (1979). The making and breaking of affectional bonds. London: Routledge.

Bolwby, J. (1980). Attachment and Loss, Vol.3. Loss, sadness and depression. London: The Hogarth Press.

Bolwby, J. (1982). Epilogue. In C. Parkes \& Stevenson-Hinde (Eds), The place of attachment in human behavior. Tavistock Publications: London.

Brazelton, T.B. (1995). O grande livro da criança. Lisboa: Editorial Presença.

Brennan, K.A., Wu, S., \& Loev, J. (1998). Adult romantic attachment and individual differences in atitudes toward physical contact in the context of adult romantic relationships. In J.A.Simpson \& W.S.Rholes (Eds), Attachment Theory and Close Relationships (pp. 394-428). New York : Guilford Press.

Diamond, N. (2001). Towards an interpersonal understanding of bodily experience. Psychodynamic Counselling, 7.1, 41-62.

Flaake, K. (2005). Girls, adolescence and the impact of bodily changes. European Journal of Women's Studies, 12, 201-212.

Fromme, D. K., Jaynes, W. E., Taylor, D. K., Hanold, E. G., Daniell, J., Rountree, J. R, \& Fromme, M. (1989). Nonverbal behavior and attitudes towards touch. Journal of Nonverbal Behavior, 13, 3-14.

Geider, B. (1996). Fathers as primary caregivers. Westport, CT: Greenwood.

Grossman, K., Grossman, K. E., Fremmer-Bombik, E., Kindler, H., Scheuerer-Englisch, H., \& Zimmermann, P. (2002). The uniqueness of the child-father attachment relationship: Fathers' sensitive and challenging play as a pivotal variable in a 16-year longitudinal study. Social Development, 11,307-331.

Gupta, M.A., \& Schork, N.J. (1995). Touch deprivation has an adverse effect on body image: Some preliminary observations. International Journal of Eating Disorders 17, 185-189.

Guidano, V.F. \& Liotti, G. (1983). Cognitive processes and emotional disorders. New York: Guilford.

Halliwell, E., \& Dittmar, H. (2003). A qualitative investigation of women's and men's body image concerns and their attitudes toward aging. Sex Roles, 49,675-684.

Hart, K., \& Kenny, M. (1997). Adherence to the super woman ideal and eating disorder symptoms among college woman. Sex Roles, 36, 461-479.

Hazan, C., \& Shaver, P. R. (1994). Attachment as an organizational framework for research on close relationships. Psychological Inquiry, 5, 1-22.

Hazan, C., \& Zeifman, D. (1999). Pair bonds as attachment. In J. Cassidy \& P. Shaver (Eds), Handbook of attachment (pp. 336-354). New York: Guildford.

Hunter, M. \& Struve, J. (1998). The Ethical Use of Touch in Psychotherapy. London: Sage Publications. 
Itakura, S. \& Imamizu, H. (1994). An exploratory study of mirror-image shape discrimination in young children: Vision and touch. Perceptual and Motor Skills, 78, 83-88.

Kazura, K. (2007). Father's qualitative and quantitative involvement: An investigation of attachment, play, and social interactions. The Journal of Men's Studies, 9, 41-57.

Klaus, M.H., \& Kennell, J. (2000). Vínculo: Construindo as bases para um apego seguro e para a independência. Porto Alegre: Artes Médicas

Lamb, M.E. (1997). The development of father-infant relationships. In M.E. Lamb (Ed), The role of the father in child development (3. ${ }^{a}$ edição). New York: Wiley

Lamb, M.E. (2004). The role of the father in child development. Hoboken, NJ: John Wiley \& Sons.

Main, M., \& Weston, D. (1981). Security of attachment to mother and father: Related to conflict behavior and readiness to establish new relationships. Child Development, 52, 932-940.

Matos, P.M., \& Costa, M.E. (2001). Family and love narratives in young adults. Comunicação apresentada no $8^{\text {th }}$ International Conference of AIFREF. Montreal: Canadá.

McCabe,M.P., Ricciardelli, L.A., \& Ridge, D. (2006). "Who thinks I need a perfect body?" Perceptions and internal dialogue among adolescents about their bodies. Sex Roles, 55, 409-419.

Merleau-Ponty, M. (1999). Fenomenologia da percepção. São Paulo: Martins Fontes.

Moita, M.G., \& Santos, M.R. (2007). Falemos de sexualidade. Um guia para pais e professores. [versão online]. Acedido em Julho, 25, 2007 em www.apf.pt/catalogo/Textos/falemos desexualidade.htm

Montagu, A. (1986). Touching: The Human Significance of Skin. New York: Harper \& Row.

Mukai, T. (1996). Mothers, peers and perceived pressure to diet among Japanese adolescent girls. Research in Adolescence, 6, 309-324.

Ogletree, M.D., Jones, R.M., \& Coyl, D.D. (2002). Fathers and their sons. Journal of Adolescent Research, 17, 418-424.

Paquette, M.C., \& Raine, K.D. (2004). The sociocultural context of adult women's body image. Social Science and Medicine, 59, 1047-1058.

Parke, R.D., \& Tinsley, B.R. (1981). The father's role in infancy: Determinants of involvement in careguiving and play. In M.E. Lamb (Ed), The role of the father in child development (2. ${ }^{a}$ edição). New York: Wiley

Poeschl, G. (2000). Trabalho doméstico e poder familiar: Práticas, normas e ideais. Análise Social, 35, 695-719.

Poeschl. G. (2001/2002). Práticas familiares e representações das diferenças entre os sexos. Cadernos de Consulta Psicológica, 17-18, 145-152.

Poeschl, G. \& Pinto, I. (2001/2002). Representações das diferenças entre os sexos e legitimação das relações entre homens e mulheres. Cadernos de Consulta Psicológica, 17-18, 171-179.

Poeschl, G. \& Serôdio, R. (1998). Roles de genre, travailfamilial et pouvoir familial: Représentations et relations. La Revue Internationale de IÉducation Familiale, 2, 2, 5-23.

Polce-Lynch, M, Myers, B.J., Kilmartin, C.T., Forssmann, F.R., \& Klewer, W. (1998). Gender and age patterns in emotional expression, body image, and self-esteem: A qualitative analysis. Sex Roles, 38, 1025-1048.

Rosen, J.C., Orosan-Weine, P., \& Tang, T. (1997). Critical experiences in the development of body image. Eating Disorders, 5, 191-204.

Salzman, J.P. (1997). Ambivalent attachment in female adolescents: Association with affective instability and eating disorders. International Journal of eating Disorders, 21, 251-259. 
Shannon, J.D., Tamis-LeMonda, C.S., London, K., \& Cabrera, N. (2002). Beyond rough and tumble: Low-income fathers' interactions and children's cognitive development at 24 months. Parenting: Science and Practice, 2, 77-104.

Shulman, S., \& Seiffge-Krenke, I. (1997). Fathers and adolescents: Clinical and developmental perspectives. New York: Routledge.

Sroufe, L.A. \& Waters (1977). Attachment as an organizational construct. Child Development, 48, 1184-1199.

Thomaz, A.C.P., Lima, M.R., Tavares, C.H., \& Oliveira, C.G. (2005). Relações afetivas entre mães e recém-nascidos a termo e pré-termo: variáveis socais e perinatais. Estudos de Psicologia, 10, 139-146.

Vincent, M. \& McCabe, M. (2000). Gender differences among adolescents in family, and peer influences on body dissatisfaction, weight loss, and binge eating behaviors. Journal of Youth and Adolescence, 29, 205-221.

Ward, A, Ramsay, R., \& Treasure, J. (2000). Attachment research in eating disorders. British Journal of Medical Psychology, 73, 35-46.

Wertheim, E.H., Paxton, S.J., Schutz, H.K., \& Muir, S.L. (1997). Why do adolescent girls watch their weight? An interview study examining sociocultural pressures to be thin. Journal of Psychosomatic Research, 2, 345-355.

\section{Body affective memories: a qualitative study about parent's role in body experience}

In this study we are interested in understand the thoughts and feelings underlying to body experience in family context. We intend to listen the adolescents voices concerning their representation about the relationship that they have with theirs bodies and with the world, listening and understand, throughout semi-structured interviews, the participants personal narratives about their body experience development. The interview focus, essentially, in the meaning construction about body along development (the living experience of relational and emotional body since childhood until the actual moment of the interview), regarding the quality of parents relationship.

Due to the absence of studies in this domain, this work intends to be an eventual contribute for the understanding of the body while relational experience and to understand how adolescents and young adults speak about their body.

KEYWORDS: Body experience; Parental relationship; Personal narratives; Adolescence. 